\title{
Why the Madurese? Ethnic Conflicts in West and East Kalimantan Compared
}

\author{
Huub de Jonge \& Gerben Nooteboom ${ }^{1}$ \\ Radboud University Nijmegen
}

\begin{abstract}
Around the recent turn of the century, violent clashes between Madurese and other ethnic groups took place in the provinces of West and Central Kalimantan. At least 1200 Madurese were killed, with several hundred thousands internally displaced. However, in the provinces of South and East Kalimantan, which also have Madurese minorities, such eruptions of violence did not occur. To reach a better understanding of the background, conditions and causes of such ethnic violence, we have compared the relationships between the Madurese and other population groups in conflict-ridden West Kalimantan and conflictfree East Kalimantan. The comparison shows that there are significant dissimilarities between the two regions with regard to the ethnic composition of the population, cultural attitudes, access to natural resources and political competition. Together with the negative characteristics attributed to the Madurese by other groups, these can largely explain why this minority, during the recent regime change, became the target of the frustrations and aspirations of others in the western part of Kalimantan but not in the eastern part.
\end{abstract}

Between 1996 and 2002, large-scale ethnic clashes took place in the province of West Kalimantan. In December 1996 and January 1997, it was the Dayak and Madurese in the district of Bengkayang who were fighting each other, resulting in between 500 and 1200, mainly Madurese, deaths and the displacement of this immigrant group from this area. In the first months of 1999, violence erupted in the district of Sambas, this time between Malays and Madurese, although the Dayak quickly joined in on the side of the Malays. There were hundreds of fatalities and once again the Madurese were compelled to flee. Thousands of Madurese left for Madura or Java, especially those who still had relatives or land in these regions. About half of the almost 70,000 displaced people from these two clashes who could not, or chose not, to leave West Kalimantan were placed in government refugee camps in the capital Pontianak. The other half moved in with relatives or acquaintances in Madurese quarters in and around the city. In 2001, after a series of smaller incidents, serious violence broke out

${ }^{1}$ Huub de Jonge undertook a short research visit to West Kalimantan in 2002, Gerben Nooteboom carried out fieldwork among the Madurese in East Kalimantan in 2003-2004 and again in 2006. Both had also previously worked among the Madurese: de Jonge in 1976-77 on Madura and Nooteboom from 1997 to 1999 in East Java. 
between these displaced Madurese and members of other ethnic groups. In the same year, violence also erupted in Sampit in Central Kalimantan with fights between Madurese and Dayak resulting in at least 500 deaths and the evacuation of almost the entire Madurese population of Central Kalimantan, about 150,000 people in total, to Madura and Java (HRW 1997; Sisi Gelap 1999; Petebang \& Sutrisno 2000; ICG 2001; Rochman Achwan et al. 2005).

The atrocities which accompanied the clashes, and the scale on which these took place, shocked the whole nation and exceeded those in other conflict areas in Indonesia. In many places in Kalimantan, mutilations, beheadings and acts of "cannibalism" accompanied the riots. Madurese homes were set on fire, their cattle killed and other possessions destroyed. Those Madurese who did escape and hide in the forests were hunted for weeks afterwards. All traces of their presence were wiped out. In Sambas, where effectively the Madurese were ethnically cleansed, only banana trees and disused mosques indicate where they once lived.

In the first months following the start of the conflict in Sampit, fears arose that violence would spread to South and East Kalimantan, other areas with a significant Madurese population. This fear was understandable as the Sampit violence had fuelled further incidents in West Kalimantan and also because Dayak from other parts of the island had joined the fight against the Madurese in Central Kalimantan. Khofifah, a national politician, referred to Samarinda, the capital of East Kalimantan, as the third 'S' after Sambas and Sampit, and the next logical link in the chain of rioting. Many saw an outbreak of violence against the Madurese in these provinces as only a matter of time. ${ }^{2}$ However, contrary to this expectation, mass ethnic violence did not break out, although in East Kalimantan in particular tensions ran high and nearly led to an outburst of violence at the end of 2001 and again in November 2005.

Over recent years, political scientists, historians, geographers and anthropologists have reflected on these conflicts, predominantly drawing on their own disciplinary backgrounds. Broadly speaking, three types of explanations are eminent: cultural, institutional, and economic (Nooteboom 2005). In the cultural explanation, the emphasis is on the cultural and symbolic differences between the ethnic groups involved (Schiller and Garang 2002). In the institutional interpretation, importance is attached to the changes

\footnotetext{
2 As reported in the Jakarta Post, March 4, 2001 "State minister for Women Empowerment/Chairperson of the National Family Planning Board Khofifah Indar Parawansa warned of the possible spread of the ethnic conflicts in Sampit and Palangkaraya to Sambas in West Kalimantan and Samarinda, the capital of East Kalimantan. 'I have informed the National Police Chief Gen. Bimantoro that there are indications the ethnic conflicts will center in those areas'."
} 
in the way the state was organised during and after Suharto's New Order (Davidson and Kammen 2002; Van Klinken 2002; Davidson 2003b; Bertrand 2004). In the economic explanation, access to natural and state resources is seen as central to any understanding of the conflicts (Peluso and Harwell 2001; Heidhues 2001). Most authors, nevertheless, agree that these explanations should not be viewed in isolation. However, even when they are combined, they do not adequately explain where the hatred against the Madurese, small minorities in all the provinces, came from and why it resulted in widespread violence in two provinces and not in others. The Madurese are the only indigenous inhabitants of Indonesia who have become targets of ethnic violence since the end of the New Order regime. Conflicts in other areas of Indonesia; in Aceh, the Moluccas and Papua; have not faced a similar dimension (Bertrand 2004: 45).

To gain a better insight into the conditions and factors that have triggered or, so far, prevented violence against the Madurese, we have compared the cultural, economic and political dimensions of the relationships between the Madurese and other ethnic groups in two provinces that are strife-torn West Kalimantan and violence-spared East Kalimantan. Such a comparison may add to a more balanced picture of the position of the Madurese in the conflicts and explain what gave them an ethnic dimension. In the following sections, we respectively describe the migration of the Madurese to West and East Kalimantan, outline their main socio-economic and cultural characteristics and deal separately with the aforementioned cultural, economic and political circumstances in each province.

\section{The Madurese in West and East Kalimantan}

For centuries, the Madurese have left their dry, infertile and overpopulated island to make a living elsewhere (de Jonge 1988; Nooteboom 2003). Already by 1800 , more Madurese lived outside Madura than on the island itself. Most of the migrants settled in Eastern Java, but in the 19th century small numbers also left for northern destinations. After 1900, migration to Kalimantan increased. In the 1920s and 1930s, West Kalimantan saw a large influx of Madurese when the area was opened up by the Dutch, and this was repeated in the 1970s and 1980s when the New Order regime started to exploit the area's natural resources on an unprecedented scale. In both periods, the demand for labour increased considerably (cf. Hendro 2001: 76-87). In East Kalimantan, which is further away from Madura and where colonial expansion started earlier, large-scale migration from Madura only began in the late 1970 s and tended to be directed at the cities of Balikpapan and Samarinda.

Most of the migrants to Kalimantan originate from Bangkalan and Sampang, the most western and poorest districts of Madura. Unlike the 
Javanese and other population groups, who were often recruited by the colonial or Indonesian administrations, the Madurese tended to migrate by choice rarely joining the so-called transmigration projects. ${ }^{3}$

According to official figures, Kalimantan had more than 5.4 million inhabitants in 2000, of which $4.92 \%$ identified themselves as Madurese. ${ }^{4}$ West Kalimantan was home to more than 3.7 million of these inhabitants, of whom slightly more than 200,000 or $5.5 \%$ of the total were Madurese (Suryadinata, Arifin \& Ananta 2003: 7, 175-178). ${ }^{5}$ The group paled in comparison next to the Dayak and Malays who each accounted for $33.8 \%$ of the population. ${ }^{6}$ The Chinese, Javanese and Buginese groupings accounted for $10 \%, 9.4 \%$ and $3.3 \%$ of the total respectively. The areas with the largest numbers of Madurese were Pontianak, the provincial capital, and the districts of Sambas (now divided into Sambas, Bengkayang and Singkawang), Outer Pontianak and Ketapang. Very few Madurese were to be found in the districts of Sangau, Sintang and Kapuas Hulu.

Before World War II, the Madurese helped in opening up forest land for plantations, or eked out a living as coolies or petty traders. As soon as they had earned enough, they bought or leased land from Dayaks or Malays, on which they planted and cultivated rice, corn, peppers, coconuts and fruit trees. Towards the end of the 1960s, many Madurese leased fields which had previously been cultivated by the Chinese when the latter were banished to the cities in the aftermath of the so-called Konfrontasi with Malaysia. $^{7}$ During the New Order period, newcomers mainly worked in the building industry, on road construction, and in the informal and trans-

${ }^{3}$ One exception is the village of Maduredjo near Martapura in South Eastern Kalimantan, which was established in 1938. Between 1938 and 1940, 408 families (1,306 people) migrated to this village (Grader 1949: 15-18; de Jonge 2004: 98). Despite this, it is remarkable how often Madurese transmigrants are mentioned in popular publications as the source of the problems.

${ }^{4}$ These figures do not include temporary workers or those who regard themselves as temporary residents. They are also based on ethnic self-definition which means that any Madurese from the island of Java who chose not to label themselves as Madurese were excluded from the total.

${ }^{5}$ According to Rochman Achwan et al. (2005: 3), in earlier population counts, the number of Madurese was always and purposefully underestimated. For example, on the eve of the 1996 ethnic conflicts, West Kalimantan had about only 90,000 recorded inhabitants of Madurese descent: less than 3\% of the more than 3.3 million inhabitants of the province (cf. Profil Kependudukan 1994; Petebang and Sutrisno 2000: 162-166).

${ }^{6}$ Undoubtedly the figures have been manipulated to show equal populations.

${ }^{7}$ In the aftermath of the Confrontation, government-initiated violence by the Dayak against the Chinese, who were seen as sympathetic towards communism, broke out (Heidhues 2003: 235-271). 
port sectors. The Madurese were dominant among the owners and drivers of minibuses and pedicabs.

Giring (2004: 31-32, 44, 64), in analysing the fighting between Dayaks and Madurese in 1997 in the village of Salatiga, $90 \mathrm{~km}$ north of Pontianak, writes that the Dayak, Malays, Javanese and Madurese competed for the fields vacated by the Chinese. In 1967 the village included about 30 Madurese households, and this number had grown to 240 in 1996, at which time the Dayak population consisted of 200 households. Despite their minority position, since the 1960s, several Madurese succeeded in gaining the position of village head, which encouraged the growth in Madurese settlers.

In East Kalimantan, the Madurese made up only $1.2 \%$ of the total population of almost 2.5 million in 2000. ${ }^{8}$ This made the Madurese the sixth largest ethnic group in East Kalimantan, behind the Javanese with $29.6 \%$, Buginese with $18.3 \%$, Banjarese with $13.9 \%$, Kutai Malay with $9.2 \%$ and the Dayak with an estimated 4.3\% (BPS 2001; Suryadinata, Arifin, and Ananta 2003: 7). Most of the Madurese in East Kalimantan live in the cities of Balikpapan and Samarinda.

Prior to World War II, most of the Madurese in this province were employed as unskilled labourers on plantations and in the mining and oil industry of Balikpapan. ${ }^{9}$ The migrants who arrived from the late 1970s onwards are mainly engaged in road construction, the recycling business (used iron, tyres), petty trade, brick making, logging, and the building and transportation sectors. Some became very successful, owning heavy machinery and large trucks. The majority, however, remain unskilled labourers in the lower echelons of society. In contrast to West Kalimantan, many Madurese are temporary migrants and seldomly settle in the countryside.

Economically, the Madurese in West Kalimantan tended to be better off than other ethnic groups although the differences were not as large as is often asserted. In East Kalimantan, conversely, they are generally poorer than members of other population groups. How they differed more fundamentally, however, was in their attitude towards work. The Madurese tended to accept any available work; for example, they were willing to collect garbage in the cities and break up rocks for the construction of roads. They would do anything to work their way up. Used as they were to hard work and saving, they were often more successful than others in similar work, and this frequently led to amazement and jealousy among other ethnic groups.

${ }^{8}$ It is likely that the real number of Madurese is much higher. The secretary of the Kerukunan Keluarga Masyarakat Madura (KKMM), the Union of Madurese estimates the number to be around 90,000 or 3.6 percent of the population.

${ }^{9}$ During the Japanese occupation an unknown number of romushas, forced labourers, were recruited from Madura to work on plantations and infrastructural projects. 
It is widely claimed that the Madurese have tended to spatially isolate themselves from others (Peluso and Harwell 2001: 103). In this, however, they do not differ from other ethnic groups who also prefer to live closely together. In the cities in West Kalimantan, the Madurese have tended to live in their own quarters, and in the countryside in their own hamlets, neighbourhoods or streets. In some villages they were a minority, in others a small majority. In Bengkayang, they generally lived alongside the Dayak; and in Sambas mainly with Malays. With both groups, as with the Chinese to whom they sold agricultural products, they maintained acceptable, even cordial, relationships for decades. Nevertheless, there were regular misunderstandings and incidents, in particular with the Dayak. Marriages between Malays and Madurese, who are both largely Muslim, were not uncommon, and most of the Madurese spoke the local Malay dialect. That mutual understanding was not as bad as it sometimes now appears, is evidenced by the fact that, on the eve of the attacks, members of different ethnic groups were still patrolling together at night and in several villages, Madurese inhabitants were both warned of the impending danger and sometimes even safeguarded by neighbours.

In East Kalimantan, the Madurese also tend to settle in close proximity to each other, often in groups based on occupation and descent. In Balikpapan and Samarinda, they live in old quarters close to the harbour and the city markets. Clusters of brick makers from rural Bangkalan can be found on the outskirts of cities on unused lands. Temporary labourers, predominantly from eastern Java and Sampang, live in barracks or deserted houses throughout the cities. Those who stay for longer do occasionally mix and interact with other ethnic groups such as the Javanese, Banjarese, Kutai Malay and Butonese, but relationships with the Buginese, the second largest ethnic group in East Kalimantan, have always been tense. Traditionally, contacts with the Dayak have been relatively cordial, although these rarely take place since most of the Dayak in East Kalimantan live in the interior of the province, far from the urban centres.

As with other ethnic groups in Kalimantan, the Madurese cherish their own norms and values and stick to their traditions. Generally speaking, they tend to live soberly, save money to invest, marry young and work together. They usually provide accommodation for arriving migrants, often relatives or former fellow-villagers, and help them to find work. As peasants, unskilled or lowly-skilled labourers they are not attracted to education. According to Hendro (2001: 72), the majority can neither read nor write. Children are often kept away from school to help in making a living. Only religious knowledge seems to be appreciated. The Madurese are, generally speaking, pious Muslims who conscientiously meet their ritual obligations. In East Kalimantan, several Madurese pesantren, religious boarding schools, have been founded, although well-to-do Madurese will often send their children to pesantren in Madura and Eastern Java. 
Some have even made the hajj. In West Kalimantan, almost all the Madurese kampong (neighbourhoods) used to have their own mosque, their own religious leaders and observe Islamic rituals and celebrations within their own community. As followers of Nahdatul Ulama (NU), they despise the modernist ideas that are popular among the Malay, Buginese and Banjarese. The migrant community has, despite some internal divisions, a high degree of solidarity, which members of other ethnic groups often see as exclusiveness.

According to many Dayak, Malay, Buginese and Banjarese informants, the Madurese have hardly adapted to their new social environment and look down on others. Their behaviour is said to be arrogant, short-tempered, macho-like, rude, uncivilised, unfair, avaricious and revengeful: all widelyused characterisations and stereotypes that have been applied to the Madurese over long periods and which, in times of crisis, acquire additional significance (de Jonge 1995). Many of the Madurese born in Kalimantan blame this negative image on newcomers, who they claim do not know how to behave, and on preman (thugs) who are often members of criminal gangs involved in illegal logging, operating brothels and gambling dens, and smuggling consumer goods from Sarawak into the country. According to them, these people cast a slur on the whole Madurese community. Dayak, Malays, Buginese and Banjarese tend to overlook the fact that these types of gangs also exist within their own groups. These various, ethnically-organised, gangs are competing hard with each other, and do not eschew violence. Nevertheless, such stereotypes have contributed a fair amount of suspicion and hatred towards the Madurese. As is often the case in such situations (see Elias 1965: 11-12), it seems that the images of the Madurese are largely determined by negative characteristics and by the worst elements in their group, whereas the images of the Dayak and others are painted by positive features and the best individuals in their midst.

An important difference between the Dayak, the Madurese and other ethnic groups concerns the 'culture of violence' prevalent in the former two groups (HRW 1997). In contrast to the Malays, the Chinese and most other immigrant groups in Kalimantan, the Dayak and the Madurese tend to resort to violence to solve serious conflicts. In the event of adultery, the theft of scarce resources, or an insult; an uneducated Madurese will resort to carok, the practice of eliminating an adversary with a sickle (celurit). Violence of this kind is always linked to a conflict between individuals or families in which honour is at stake and members of the wider group will not interfere. If the family of the victim of a 'revenge' attack disputes the justification, a vendetta may result that can last for generations (Smith 1997, 2000; 2004; de Jonge 2002; Latief Wiyata 2002). Among the Dayak, a conflict is preferably resolved using fists, which is without the shedding of blood. However, if blood does flow, the whole clan will join in and violence can easily become communal. Participants drink from the mangkok merah, a red bowl filled with chicken blood and other ingredients that symbolise 
warfare. After the strife has run its course, reconciliation takes place and compensation is paid by the losing party (HRW 1997; Schiller and Garang 2002: 244; Peluso 2006). In disputes which get out of hand between the Dayak and Malays or Chinese, the same procedure has been followed. In the recent past, several similar peace settlements have also been concluded with the Madurese, but the Dayak claim that the Madurese seldom observe the peace terms. As a result of this ethnic distrust, most of the Madurese from West Kalimantan are not welcome if they try to return to their former villages from the refugee camps. Consequently, after the camps were closed a few years ago, many chose to set up home in the capital, while a smaller number settled in resettlement locations around the capital. ${ }^{10}$

\section{Violence in West Kalimantan}

The number of communal clashes between Madurese and other population groups prior to the ethnic clashes at the end of the 1990s is not as large as is often supposed (HRW 1997; Giring 2004: 167-169). Petebang and Sutrisno (2000: 203) refer to 'riots' in 1933 in Sukadana (in the district of Ketapang that was not involved in the recent turmoil), but in reality this was a revolt by a small number of Madurese who were sold as slaves to local employers by a boat captain. For a long period, there were no conflicts between the Dayak and the Madurese involving large numbers of people. It was not until 1977, when a Madurese stabbed a Dayak policeman that riots broke out in Samalantan killing five and destroying 72 houses. In 1979, an attack by some Madurese on a Dayak again led to communal clashes in the same area (resulting in 20 killed and 92 houses burned down). Following a peace settlement, orchestrated by the provincial government, a memorial was erected to help keep the agreement alive. Unfortunately this did not work, and in 1983 and 1993 both parties again confronted each other. Naturally, these incidents increased tensions between the Madurese and the Dayak, and also had detrimental effects on the relationship between the Madurese and the Malays, but they were not in themselves the cause of the ethnic 'wars' that broke out in the late-1990s. Nevertheless, they did reinforce existing images, contributing to a climate of hatred and fear, and served to identify scapegoats for the prevailing discontent, thus facilitating mass mobilisation against the Madurese.

It is generally accepted that characteristics attributed to population groups are, in themselves, seldom the reasons for taking up arms, but rather that it is changes in local or regional circumstances, or changes in the

10 Those who did not opt for a resettlement location got a lump sum to find a new place on their own, which in practice meant that they moved to a new location in or around the capital. 
relationship with the wider society, which pits ethnic groups against each other. With regard to the conflicts between Dayaks and Madurese, several authors have drawn attention to the economic marginalisation of the Dayak in East Kalimantan during the New Order regime. Peluso and Harwell (2001) have described how huge tracts of forest areas over which the Dayak had exerted territorial rights in colonial times were juristically reclassified as state land during the Orde Baru period. Whereas the colonial state had defined all forest land used by the Dayak for slash and burn cultivation and meeting other needs as 'native' lands controlled by customary law, and classified the unused forest as nature, under Suharto, the land rights of the Dayak were severely restricted, with any land not in constant use, including fallow land, being categorized and appropriated as state land (Wadley 2003). Then, as part of the development policy for the province and the nation, it was redistributed in small parcels to migrants and in larger parcels among plantation owners and logging corporations in which, more often than not, the state and its manifestations, such as the army and provincial branches of ministries, had important stakes. The Dayak not only had to resettle and to tolerate outsiders settling on land to which they believed they had customary titles, but they also witnessed them gaining most of the proceeds of the economic developments taking place. Most of the resources, jobs and profits went to people from outside, people who looked down on them or ignored their presence, culture and history. The Dayak had effectively become excluded from land they considered as their own and blocked from taking part in new enterprises. According to Peluso and Harwell (2001: 94) "The New Order government established boundaries around villages, redesigned whole working landscapes, and ultimately transformed the lifestyles of thousands of people."

Not only economically, but also culturally and politically, the Dayak were sidelined during the Suharto regime. After 1965 they lost almost all the positions and privileges they had enjoyed in the late colonial period and during Sukarno's regime. The holders of power in Jakarta now saw them as second-rate compatriots who, at least for the time being, lacked the characteristics of modern 'Indonesian' citizens (Bertrand 2004: 45). Their culture was considered primitive and backward, and not in line with the national culture. The representatives of the group were seen as unsuitable for fulfilling the political and administrative functions necessary for the realisation of Indonesia's national goals. At the end of the colonial period, and throughout the Old Order of Sukarno, the Dayak were represented at all administrative levels in the region. In contrast to the local Malays and newcomers, during the New Order they were virtually excluded from positions of power at the local, district and provincial levels (Davidson 2003a).

In the 1990s, the Dayak, made up of various sub-groups with distinct cultural characteristics, began to agitate in writing (in particular in the 
Kalimantan Review) and through actions against their perceived injustices. According to Davidson the protests were, above all, the result of activities by several Dayak NGOs who had made the various Dayak groups conscious of their shared deprivation and the urgent need to fight together for a better future. They created in his view an unprecedented feeling of unity, solidarity and political awareness. It was this combination of sensitivity, revived self-consciousness and fighting spirit which led to the clashes of 1997, in the final years of the Suharto regime (Davidson 2003b: 70-74).

That the Dayak took out their frustrations and anger on the Madurese was primarily due to the fact that, within their daily environment, they felt the greatest distance from this group, with whom they also tended to have more disputes and conflicts than with others. Further, the arrival of the majority of the Madurese had coincided with the heyday of the New Order. Thus, although they were not responsible for the radical political and economic changes, they visibly belonged to the 'beneficiaries' (Peluso and Harwell 2001: 114). Day in, day out, the Dayak watched as the Madurese cultivated what they saw as their land that had been taken away by the state and sold or leased to migrants. The Madurese were an easier prey for their wrath than the powerful plantation and logging companies against which they had also regularly campaigned but without success (Ibid. 105). Last, but not least, no other group lent itself so readily for the creation of an image of 'the enemy'. The existing stereotypes of the Madurese, whether true or not, were opportune in turning this ethnic group into a scapegoat.

During the reformasi (political reformation) which followed Suharto stepping down, the Dayak saw a chance to become more prominent in the political field. Their activities, however, alarmed the Malays, who were afraid of losing their privileged position in the provincial bureaucracy and the wider economy. As a counteraction, the Malays used the newlyintroduced decentralisation policy to begin ethnic revitalisation in their circles. According to Davidson (2003b: 79-80), this was the time that the Forum Komunikasi Pemuda Melayu (FKPM; Communication Forum of Young Malays), an organisation dominated by prominent figures and businessmen with dubious reputations, was able to channel the discontent and also, in cooperation with youth and preman, vent their frustrations on the Madurese. Although the Malays had many cultural similarities with their Muslim neighbours, and fewer complaints against them than against the Dayak, in their efforts to secure their own interests they tarred both with the same brush. By violently distancing themselves from the Madurese, they also tried to underline their own identity. In comparison with the Dayak NGO, which created a climate that encouraged the clashes, the FKPM also played a leading role in the chasing away and liquidation of the Madurese in Sambas in 1999. In the process of reawakening the Malay identity, the kraton (palaces) of the former Pontianak and Sambas sultanates 
became centres of Malay history and culture. In January 2002, for example, a Pertemuan Adat Melayu Sernatau (International Meeting on Malay Culture) was held in Sambas, attended by representatives of Brunei, Serawak and the Philippines, with the explicit goal of strengthening the identity and cooperation of Malays both at home and abroad.

In both the 1997 and 1999 clashes, the Dayak and the Malays were initially reacting to acts of aggression by the Madurese. However, it is important to recognise that, although the Madurese were often the first to take up arms, they were never intending to provoke or commit communal violence. As far as is known, they never left their own areas to attack outsiders, with the exception of putting up barricades on main roads to intercept potential adversaries. Their part in the communal clashes was defensive rather than offensive. The clashes could possibly have been prevented if the army and the police, who have both been accused of lacking impartiality, had taken the earlier signs of animosity more seriously and been capable of the job at hand. Instead they were overtaken by events and in the initial weeks, they restricted activities to assisting in the evacuation of the Madurese. Only later did they try to intervene and halt the violence.

The vulnerability of the Madurese was greater because, unlike the Dayak and the Malays, they did not possess powerful elite. Among their religious leaders there was hardly anyone whose authority went beyond the local community. The only wider organisation that existed before the ethnic riots was a branch of the Ikatan Keluarga Besar Madura (Union of Madurese Communities) which had been founded in the 1980s by chiefof-staff General Hartono with the ulterior motive of gaining Madurese votes for Golkar, the political party on which the New Order relied. This organisation, which had had good contacts with provincial authorities, now had (after Suharto's fall) nothing to offer. After the evacuation of the Madurese, a few new interest groups were founded, including the Yayasan Korban Kerusuhan Sambas (Foundation for the victims of the Riots in Sambas) and a branch of the national Himpunan Mahasiswa Madura (Association of Madurese Students). Together with the Ikatan Keluarga Madura, the successor to Hartono's organisation, they acted as representatives of the displaced population, distributed supplies from relief organisations, co-ordinated resettlement activities and took part in the deliberations about the future of the Madurese. However, due to opposition from all sides, plus internal disagreements and corruption, they had little say in the future, and were forced to accept that an immediate return to their village was out of the question for the Madurese.

The ethnic cleansing of the Madurese from the Pontianak hinterland does not mean that violence is a thing of the past. Both the Dayak and the Malays have not yet achieved what they are aiming for: a far-reaching cultural and political domination over the whole province. The Dayak have taken the most important administrative and political positions in Bengkayang, 
while the Malays have similarly acted in Sambas. Both factions are, however, far from satisfied and continue to aggressively compete to get ahead of each other. So far, they have aimed their violence at third parties but, according to members of both ethnic groups, it is only a matter of time before the Malays and the Dayak violently confront each other.

\section{Echoes of violence in East Kalimantan}

In contrast to West Kalimantan, relationships between Madurese migrants and indigenous Malay and Dayak populations, for a long time, have not been marked by any hatred, resource competition and violent conflicts. It was only after the ethnic cleansing in Sambas and Sampit that violent images of Madurese and Dayaks spread to East Kalimantan. In both 2001 and 2005, the Government of East Kalimantan could barely prevent Dayak groups, mostly originating from farther afield, attacking the Madurese. Until that time, the Madurese and the Dayak people had co-existed rather peacefully.

However, the relationship between the Madurese and the Buginese had been much more explosive (Acciaioli 1999: 242). Since the arrival of large groups of migrants in the late-1970s, many Madurese have occupied the same economic niches in trade, transport and illegal activities as Buginese migrants from Sulawesi. This has led to tensions and conflicts between the groups, especially at market places and harbours. During the 1980s and early 1990s, in the provincial capital Samarinda and the oil city of Balikpapan, violence between Buginese and Madurese gangs was rampant. The chain of violence started in 1980 when a Buginese gang leader (jago) was killed at the market after he had offended a Madurese. Looking for revenge, Buginese gang members searched for the Madurese culprit in order to kill him. At first they failed as the perpetrator got help from his Madurese friends, but later he was found and killed. Since then, there have been regular clashes between Madurese and Buginese resulting in dozens of casualties. Madurese women and children have also suffered harassment and this has led to retaliatory violence. The violence has also created a climate of fear and insecurity among other ethnic groups.

The government was unable or unwilling to stop this violence, and the police tolerated it as long as the violence remained within boundaries. Only if larger state or elite interests were endangered would the violence be suppressed, often with strong backing from the military. Among the police and local business elites, there were people who maintained close ties with the Madurese as the immigrants are good watchmen and security guards, and reliable caretakers of illegal businesses such as gambling dens, brothels, and illegal logging and trade companies. In return for a share of the profit, the police tolerated some of these activities and shielded 
perpetrators from punishment as long as the activities remained out of the public eye. They even regularly recruited local Madurese strongmen to suppress criminality or to control illicit activities (Nooteboom 2005: 168-173). Those who were happy to fish in muddy waters undoubtedly benefited from a certain level of violence (Van Klinken 2002: 70).

The Madurese also profited from their good relationships with police officers and business elites. They managed to maintain these good connections with the police until the mid-1990s. From then on, however, Madurese gang leaders gradually lost their influential connections due to the reallocation of senior police officers and the waning of Suharto's New Order regime which had safeguarded the position of Madurese and Javanese migrants. When economic and political turmoil spread across the country as a result of the 1997 economic crisis and the violent outbreaks against the Madurese in West and Central Kalimantan began, the Madurese found themselves isolated from local and regional politicians. A shift in elites had taken place. When Suharto's old cronies disappeared from the scene, regionally-rooted, older elites plus new leaders of Kutai Malay, Banjarese, Buginese and Dayak descent took their chances. Suddenly, ethnicity, carefully suppressed during the New Order period, had become an issue, and oncedowntrodden groups such as adat leaders and Dayaks tried to get a foothold in regional politics. This process accelerated after the decentralisation laws of 1999 which offered greater regional autonomy to 'indigenous people' (putra daerah).

The new leaders succeeded in suppressing the feuds between the Madurese and the Buginese, and eliminated most of the gangs, although fights among thugs and thieves at markets and in bars are still part of everyday life. Given that these fights are now perceived by local people as inter-ethnic violence, tensions remain. Between September 2003 and February 2004, at least eight fights took place between Madurese and Buginese in which at least four people were killed and several others severely wounded. In contrast with similar events in the past, the provincial governments reacted nervously to these clashes and killings. Fearing that it might escalate into ethnic violence, they forbade all references to ethnicity in the media, ordered increased police involvement, banned large gatherings of Madurese, and tried to limit the number of new Madurese immigrants. ${ }^{11}$ Given the violence in West and Central Kalimantan, with the resulting

\footnotetext{
11 The government banned Madurese public meetings and established a zerotolerance policy towards fights at hotspots such as market places, cockfighting arenas and brothels. Indonesian army forces were kept on alert, and police troops guarded Madurese areas and strategic places. Security officials from the police's intelligence department (Intel) infiltrated potential hotspots and stopped any fights from spreading by firing into the air, capturing ringleaders, or even shooting some people in the legs.
} 
defeat of the Madurese, the Madurese position was further weakened in East Kalimantan.

The mass violence in West and Central Kalimantan towards the Madurese came as a total surprise to them and further traumatised the Madurese community in East Kalimantan. Although there were no real violent acts against the Madurese in East Kalimantan, the fear of spreading ethnic violence was based on more than mere rumours. In Samarinda, Dayak people had allegedly threatened to burn Madurese brick-making sheds. The spreading news of mass violence in West and Central Kalimantan also produced very strong images and anti-Madurese sentiments in East Kalimantan. Although broadcasts on the violence in Indonesia were then banned, the damage had been done. Images and videos of murdered and beheaded Madurese and lurid stories were circulating within the province. For the Madurese, Kalimantan was never going to be the same again.

Essentially, there were three types of reaction among the Madurese at the time of the conflicts in Sambas and Sampit. The first reaction was one of disbelief: many did not really believe that violence would or could ever spread to East Kalimantan as there had never been large-scale violence against the Madurese there. The second group reacted with shock to the news that the violence had spread from Sambas to Sampit, and realised it could spread further to East Kalimantan. However, they relied on their fierce reputation, their good relations with their neighbours, on police officers and the local elite, and preferred not to leave their properties, businesses and occupations behind. The last group, made up of mostly poor labourers and peddlers from the inner cities, simply feared for their future and tried to escape to Madura as quickly as possible. They flocked to the harbours taking only the bare necessities such as spare clothes, jewellery and money. Ultimately, about 10 to 15 percent of the Madurese actually left.

After the Sampit affair, the provincial government of East Kalimantan followed a pro-active strategy. The governor, in close cooperation with the police and the army, brought ethnic leaders, some NGOs and university lecturers together, and forced the ethnic fractions to make peace in public. The Madurese were under-represented in these meetings. The first meeting was held in the old stadium of Samarinda, with the following monthly meetings in the prestigious Bumi Senyiur Hotel in Samarinda under the banner of Forum Kommunikasi Persaudaraan Masyarakat Kalimantan Timur (FKPMKT), the Communication Forum for Reconcilement of the East Kalimantan People. ${ }^{12}$ Only the most important ethnic groups were represented in this forum. In 2001, another forum was created, the Forum Komunikasi Antar Suku (FORKAS), the Inter-Ethnic Communication

${ }^{12}$ See also Van Klinken, 2002: 50. 
Forum. This forum included a Madurese religious leader, but he only represented part of the Madurese community. The provincial government forced him to re-establish the Kerukunan Keluarga Masyarakat Madura (KKMM), the Union of Madurese, an ethnic association similar to the ethnic associations represented in the FKPMKT. The KKMM, however, was never a success due to diverging interests among ethnic sub-factions, classes and business leaders. This reflects the fact that the Madurese in East Kalimantan were poorly organised. Although in the eyes of outsiders they are seen as highly united (kompak), internally, they are strongly divided and lack good spokesmen.

In November 2005, tensions rose sky high after the son of a Dayak adat leader was stabbed by a Madurese security guard, with this incident nearly provoking mass violence. ${ }^{13}$ Large numbers of Dayak warriors from all parts of Kalimantan came to Samarinda to seek revenge. One day after the fight, one Madurese brick-maker was murdered and another wounded. ${ }^{14}$ Thousands of Madurese peddlers and labourers wanted to leave for Madura at this point, although only a few hundred actually left. Fortunately, no further violence occurred, with politicians, the military and the police making great efforts to prevent any escalation of the conflict. The mayor of Samarinda and the vice-mayor, who was a Dayak, as well as police and army representatives tried hard to re-establish FORKAS, which had been used before, and organised a large peacemaking ritual to calm the people down.

Although the symbolic power of intercultural communication and the reconciliation ritual were significant, and might have been crucial in curtailing the activities of militant ethnic leaders, for ordinary Madurese migrants the dialogue had little meaning as they did not feel represented. There has never been any form of formal Madurese organisation in East Kalimantan, and the influence of the KKMM remains limited. Further, internal divisions and personal power politics have further weakened its position. Few interethnic conflicts have ever been settled by the KKMM,

${ }^{13}$ On November 7, 2005, in the Royal karaoke bar in Samarinda, a Dayak guest got drunk and hassled a woman at the bar. The security guard ordered him to leave the establishment. The guest went to his car, took out a piece of iron and started to hit the security guard. After the third hit, the security guard pulled out a large knife and stabbed the man in the stomach. He was taken to hospital in a serious condition. Soon people found out that the security guard was of Madurese descent. Dayak groups proclaimed that for each Dayak who died, 40 Madurese should also die. The military made great efforts to prevent the man from dying and, according to some sources; a dozen soldiers were ordered to donate blood. Eventually, the Dayak recovered.

${ }^{14}$ It is not certain that the Madurese was murdered by Dayak or by others who wanted to further fuel the conflict. 
and the tough governmental judicial policies have generally been rather disadvantageous for the Madurese. During the 2005 tensions, the KKMM's position was somewhat enhanced, and it is likely that the threat of violence will further strengthen the role of Madurese organisations in the future.

\section{Why the Madurese?}

A comparison between West and East Kalimantan helps to reach a better understanding of the resentment and violence against the Madurese residents while, at the same time, elucidating the rise and course of the ethnic tensions and conflicts. In both provinces, the Madurese were a minority, although their presence was significantly stronger in the western province. In West Kalimantan they are heavily outnumbered by local Dayak and Malays, whereas in East Kalimantan, the ethnic composition of the population is much more varied. In the latter it is an immigrant group, the Javanese, which has numerical superiority. In both areas, the Madurese migrants originate from the same poor areas on Madura, share an identical cultural background - including a similar culture of violence - tend to settle in their own communities, marry amongst themselves, and to some extent isolate themselves in their social and cultural lives from other ethnic groups. In the western part of Kalimantan, where Madurese migrants arrived much earlier, the younger generations have lost contact with the island of their ancestors. In the eastern part, migration started later, and migrants tend to maintain strong ties with their native soil. In the west, where the older generation preferred to make a living in the countryside, newcomers, like the Madurese in East Kalimantan, try to find work in the cities.

These differences in themselves do not explain why the Madurese became the main victims of ethnic violence in West Kalimantan, or why there has been little violence in East Kalimantan. If we look, however, at the economic, political and cultural dimensions of ethnic relationships in both provinces, they take on another meaning. In West Kalimantan, there has been strong competition for agricultural resources, especially between Malays, Dayaks and Madurese, and this has led to frustration and aggression. One of the main reasons for this is especially the appropriation of Dayak land by the state during the New Order regime, and the distribution of a considerable part of this land to newcomers, including a sizable number of Madurese. Madurese settling in resource-rich East Kalimantan have been less dependent on agriculture, and the only ethnic group with which the Madurese here compete, in this case for jobs and business opportunities, is the Buginese.

Competition in West Kalimantan has not been restricted to the economic field. During the Suharto years, Dayak, and to a lesser degree Malays 
had to hand over powerful positions in the provincial bureaucracy to civil servants (often Javanese) from outside Kalimantan and to give up their political aspirations. During the declining years of the New Order, the elite of both groups were preparing to reclaim these lost positions, a contest that eventually involved trampling the Madurese (cf. Van Klinken 2002). Conversely, in East Kalimantan, the local elites had nothing to fear from the Orde Baru bureaucracy since their interests corresponded. Even after the fall of Suharto they retained their positions. In this region, there was therefore no reason to incriminate the Madurese and some were happy to cooperate with members of this group. Thus, while in the western province, local elite seized the opportunity to make a comeback, in the east the elite put their efforts into maintaining their positions. Any outbreak of mass violence would have threatened their interests. To date, the East Kalimantan government continues to be quite successful in preventing ethnic violence.

We would argue that it was these specific conditions which made West Kalimantan more susceptible to violence than East Kalimantan, even though they do not really explain why the violence was primarily directed to the Madurese. The reason for that can, in our opinion, only be traced back to the need for a scapegoat, a role to which the despised and culturally distinct Madurese were suited. They were a small, controversial and vulnerable group, whose comings and goings incited resentment, who were involved in a series of both small and larger violent incidents, and about whom negative stereotypes abounded. Although their differences to other ethnic groups were largely imagined (cf. Schlee 2002: 7-9), they formed a fertile basis on which to perpetuate violence. Hence, the underlying problems could be reduced to manageable proportions, ideas and categories.

As is often the case, once the violence had started, the real causes of the conflict were pushed into the background. The accusations assumed a life of their own and resulted in a violent image of an enemy that was continually reproduced and re-invented and spread to other parts of the island. In East Kalimantan, where relationships between the Madurese and most other groups had not been problematic, antagonism and aggression towards the Madurese grew. The threat of violence has become closer and potentially now endangers the lives of the Madurese there. Simply being Madurese is enough to make one an enemy and perhaps even a victim. The course of the conflict has taken over the cause. As Schlee (2002: 28) observed in other violent-prone areas: "The conflict itself is the ground on which hatred is cultivated." 


\section{References}

Acciaioli, Greg (1999) "Principles and Strategies of Bugis Migration: Some Contextual Factors Relating to Ethnic Conflict", Masyarakat Indonesia XXV (2):239-263.

Bertrand, Jacques (2004) Nationalism and Ethnic Conflict in Indonesia. Cambridge: Cambridge University Press.

BPS (2001) Population of Indonesia: Results of the 2000 Population Census. Jakarta: Badan Pusat Statistik.

Davidson, Jamie S. (2003a) "Primitive' Politics: The Rise and Fall of the Dayak Unity Party in West Kalimantan, Indonesia”, Singapore: Asia Research Institute. [Working Paper Series no. 9.]

- (2003b) "The Politics of Violence on an Indonesian Periphery", South East Asia Research 11 (1):59-89.

Davidson, Jamie S., and Douglas Kammen (2002) "Indonesia's Unknown War and the Lineages of Violence in West Kalimantan", Indonesia 73:53-87.

Elias, Norbert (1976) "Een theoretisch essay over gevestigden en buitenstaanders", in Norbert Elias \& John L. Scotson, De gevestigden en de buitenstaanders. Utrecht: Het Spectrum, pp. 7-46.

Giring (2004) Madura di mata Dayak. Dari konflik ke rekonsiliasi. Yogyakarta: Galang Press.

Grader, J. (1949) Het Madura Welvaartsfonds (1937-1941). Buitenzorg: Bureau der Landinrichting.

Heidhues, Mary S. (2001) "Kalimantan Barat 1967-1999. Violence on the Periphery", in Ingrid Wessel \& Georgia Wimhofer, eds, Violence in Indonesia. Hamburg: Ambera, pp. 139-151.

— (2003) Golddiggers, Farmers, and Traders in the "Chinese Districts" of West Kalimantan, Indonesia. Ithaca: SEAP. [Studies on Southeast Asia no. 34.]

Hendro, Suroyo Sudagung (2001) Mengurai pertikaian etnis: Migrasi swakarsa etnis Madura ke Kalimantan Barat. Jakarta: Institut Studi Arus Informasi.

HRW (1997) Indonesia: Communal Violence in West Kalimantan. New York: Human Rights Watch.

ICG (2001) Communal Violence in Indonesia: Lessons from Kalimantan. Jakarta/Brussels: International Crisis Group. [ISG Asia Report no. 19.]

Jonge, Huub de (1988) Handelaren en handlangers. Ondernemerschap, economische ontwikkeling en islam op Madura. Dordrecht: Foris Publications. [Verhandelingen KITLV no. 132.]

- (1995) "Stereotypes of the Madurese", in Kees van Dijk, Huub de Jonge \& Elly Touwen-Bouwsma, eds, Across Madura Strait. The Dynamics of an Insular Society. Leiden: KITLV Press, pp. 7-24.

(2002) "Rather White Bones than White Eyes: Violent Self-help among the Madurese", in Frans Hüsken \& Huub de Jonge, eds, Violence and Vengeance: Discontent and Conflict in New Order Indonesia. Saarbrücken: Verlag für Entwicklungspolitik Saarbrücken GmbH, pp. 143-156.

— (2004) "State and Welfare in the Late Colonial Period: The Madura Welfare Fund", Asian Fournal of Social Science 32 (1):51-104.

Latief Wiyata A. (2002) Carok. Konflik kekerasan dan harga diri orang Madura. Yogyakarta: LkiS. 
Nooteboom, Gerben (2003) A Matter of Style: Social Security and Livelihood in Upland East Java. PhD thesis. Department of Anthropology, Radboud University Nijmegen, The Netherlands.

_ (2005) "Competition, Collateral Damage, or 'Just Accidents'? Three Explanations of Ethnic Violence in Indonesia", Bïdragen tot de Taal-, Land-en Volkenkunde 161(4): $565-575$.

- (2005) "Ondernemers en politie", in Frans Hüsken \& Huub de Jonge, eds, Schemerzones \& schaduwzijden: Opstellen over ambiguiteit in samenlevingen. Nijmegen: Roelants, pp. 168-173.

Peluso, Nancy Lee \& Emily Harwell (2001) "Territory, Custom, and the Cultural Politics of Ethnic War in West Kalimantan, Indonesia", in Nancy Lee Peluso \& Michael Watts, eds, Violent Environments. Ithaca: Cornell University Press, pp. 83-116.

Peluso, Nancy Lee (2006) "Passing the Red Bowl: Creating Community Identity through Violence in West Kalimatan, 1967-1997", in Charles A. Coppel, ed., Violent Conflicts in Indonesia: Analysis, Representation, Resolution. London: Routledge, pp. 106-128.

Petebang, Edi \& Eri Sutrisno, eds (2000) Konflik Etnis di Sambas. Jakarta: Institut Studi Arus Informasi.

Profil Kependudukan (1994) Profil Kependudukan Propinsi Kalimantan Barat. Pontianak: Kantor Statistik Kalbar.

Rochwan, Achwan et al. (2005) Overcoming Violent Conflict. Vol. 1. Peace and Development Analysis in West Kalimantan, Central Kalimantan and Madura. Jakarta: CPRU-UNDO, LabSosio and Bappenas.

Schiller, Anne \& Bambang Garang (2002) "Religion and Inter-ethnic Violence in Indonesia", Fournal of Contemporary Asia 32 (2):244-254.

Schlee, Günter, ed. (2002) Imagined Differences: Hatred and the Construction of Identity. Münster: Lit Verlag. [Market, Culture and Society no. 5.]

Sisi Gelap (1999) Sisi gelap Kalimantan Barat. Perseterunan etnis Dayak-Madura 1997. Jakarta: Institut Stusi Arus Informasi \& Institute Dayakology Research and Development.

Suryadinata, Leo, Evi Nurvidya Arifin \& Aris Ananta (2003) Indonesia's Population: Ethnicity and Religion in a Changing Political Landscape. Singapore: Institute of Southeast Asian Studies. [Indonesian's Population Series no. 1.]

Van Klinken, Gerry (2002) "Indonesia's New Ethnic Elites", in Henk SchulteNordholt \& Irwan Abdullah, eds, Indonesia: In Search of Transition. Yogyakarta: Pustaka Pelajar, pp. 67-105.

Smith, Glenn (1997) "Carok Violence in Madura: From Historical Conditions to Contemporary Manifestations", Folk - Fournal of the Danish Ethnographic Society 39: $57-75$.

- (2000) "Emotions et décisions violentes: le cas madourais", in Adam Kiss, ed., Asie-Europe: Les Emotions. Paris: Harmattan, pp. 145-199.

- (2004) "Violence in Madura: The Interplay of Resource, Culture, and History", in Myrdene Anderson, ed., Cultural Shaping of Violence: Victimization, Escalation, Response. West Lafayette, Indiana: Purdue University Press, pp. 207-213.

Wadley, Reed L (2003) "Lines in the Forest. Internal Territorialization and Local Accommodation in West Kalimantan, Indonesia (1865-1979)", South East Asia Research 11 (1): 91-112. 